\title{
Skapt av viten
}

\section{Sammendrag}

Nyheten om sauen Dolly, verdens første klonede pattedyr, ble sluppet i januar 1997. Reaksjonene var sterke og umiddelbare: Kunne man klone en sau, kunne man prinsipielt også klone et menneske. Spørsmålet var ikke lenger om vi kan, men om vi vil.

Dolly ble det til da ypperste symbolet på ny bioteknologi, og debatten som fulgte demonstrerte den ambivalente blandingen av fascinasjon og frykt som moderne bioteknologi forbindes med. Bioteknologien kan gripe inn i og omkode naturen, og derved potensielt også endre naturen og menneskeheten.

Da Dolly ble født, var det én formulering som gikk igjen: Det var som om science fiction ble virkelighet. Denne artikkelen belyser hvordan reaksjonene var tett forbundet med gamle kulturelle forestillinger om kunstige mennesker.

\section{Siv Frøydis Berg*} siv.berg@nb.no

Senter for teknologi, innovasjon og kultur Universitetet i Oslo

Postboks 1108 Blindern 0317 Oslo

* Nåværende adresse:

Avdeling for fag og forskning

Nasjonalbiblioteket

Postboks 2674 Solli

0203 Oslo

Ordet «klon» kommer av det greske klonos, og betyr stikling, gren, avlegger. Den skotske genetikeren Ian Wilmut brukte imidlertid aldri dette ordet i Nature, der han i februar 1997 presenterte eksperimentet som raskt ble kjent verden over som den klonede sauen Dolly.

Dolly var det første pattedyr klonet fra en adult stamcelle: hun ble skapt av det genetiske materialet fra en seksårig søye. Dette til forskjell fra andre vellykkede forsøk med kloning av dyr før Dolly, der donorcellen ble tatt direkte fra et embryo. Kloningsprosessen involverer «kjerneoverføring». Donorcellen (som inneholder alt sitt DNA) fusjoneres så med en eggcelle der DNA er fjernet. Når fusjonen er gjennomført, implanteres dette embryoet - som er i utvikling, i en surrogatmor.

I dag, mer enn ti år etter Dolly, er kloning blitt en del av den bioteknologiske normalvitenskapen. Terapeutisk, ikke reproduktiv kloning, står i fokus. Dolly betraktes imidlertid fortsatt som et vannskille innenfor bioteknologien. Hun er ikke minst etablert som et meningstungt, om enn mangetydig kulturelt symbol, omtalt som både et «kulturelt ikon» og en «Rorschach test» (2).

Analogien mellom det laboratorieskapte pattedyret og mennesket selv ble trukket umiddelbart: Kunne man klone en sau, kunne man i prinsippet også klone et menneske. Spørsmålet offentlighet og publikum stilte seg etter nyheten om Dolly, var ikke lenger om mennesker kunne klones, men når. Og utgangspunktet for diskusjonene var ikke om vi kan, men om vi bør. Viktige stemmer som blant andre EUs president, FNs generalsekretær, Verdens helseorganisasjon og daværende president i USA, Bill Clinton, forlangte forbud mot videre forskning inntil konsekvensene var nøye utredet. Mediene var fulle av spekulasjoner om hva dette kunne medføre. Vatikanet slo fast sin prinsipielle begrunnelse: Kanskje kunne mennesket skape en kropp - men bare Gud kunne skape en sjel. Kloningen av Dolly ble raskt betraktet som et etisk anliggende, og hennes ankomst fikk politiske og juridiske konsekvenser, blant annet gjennom moratorier og lovendring av forskning på befruktede egg (3).

I denne artikkelen ser jeg ikke på de konkrete reaksjonene på Dolly, men tar utgangspunkt i uroen hun skapte, ved å stille spørsmålene: Hvorfor ble referanser til fiksjonens verden i så sterk grad trukket inn for å bringe den nye teknologien og dens potensielle konsekvenser på begrep? Hvordan kan ny teknologi forstås i lys av gamle myter og kulturelle forestillinger?

\section{Ny teknologi, gamle spørsmål}

Virkeliggjøringen av den nye reproduktive teknologien åpnet for en rekke spørsmål av filosofisk, etisk og eksistensiell karakter. Som andre bioteknologier berørte kloningen våre holdninger til kunnskap og vitenskap generelt, og reflekterte den veldokumenterte ambivalens som knyttes til bioteknologi: kulturelle forventninger til ny og eventyrlig kunnskap og dens uforutsette konsekvenser. Men der tidligere kontroversielle bioteknologier som in vitro-fertilisering og genteknologi gjorde det mulig å gripe inn i reproduksjonen, manipulere arvematerialet og derved endre mennesket, synes kloningen å åpne for muligheten av å erstatte mennesket. Det originale individet kunne erstattes med identisk utseende kopier, som kanskje også hadde ervervet det opprinnelige individets unikhet. Den potensielle muligheten for å skape menneskets stedfortredere truer en kulturelt utbredt forestilling om at ethvert individ er enestående og unikt, og utfordrer derved bokstavelig talt kjernen i en utbredt oppfattelse av hva et menneske er.

I moderne forestillinger om individets

\section{Hovedbudskap}

- Da sauen Dolly ble født, vakte det stor debatt

- Reaksjonene på kloning hentet liv fra gamle kulturelle forestillinger

- Viktige referansepunkter var Frankenstein og Brave new world

- Slik ble ny teknologi knyttet til gamle verdispørsmål 


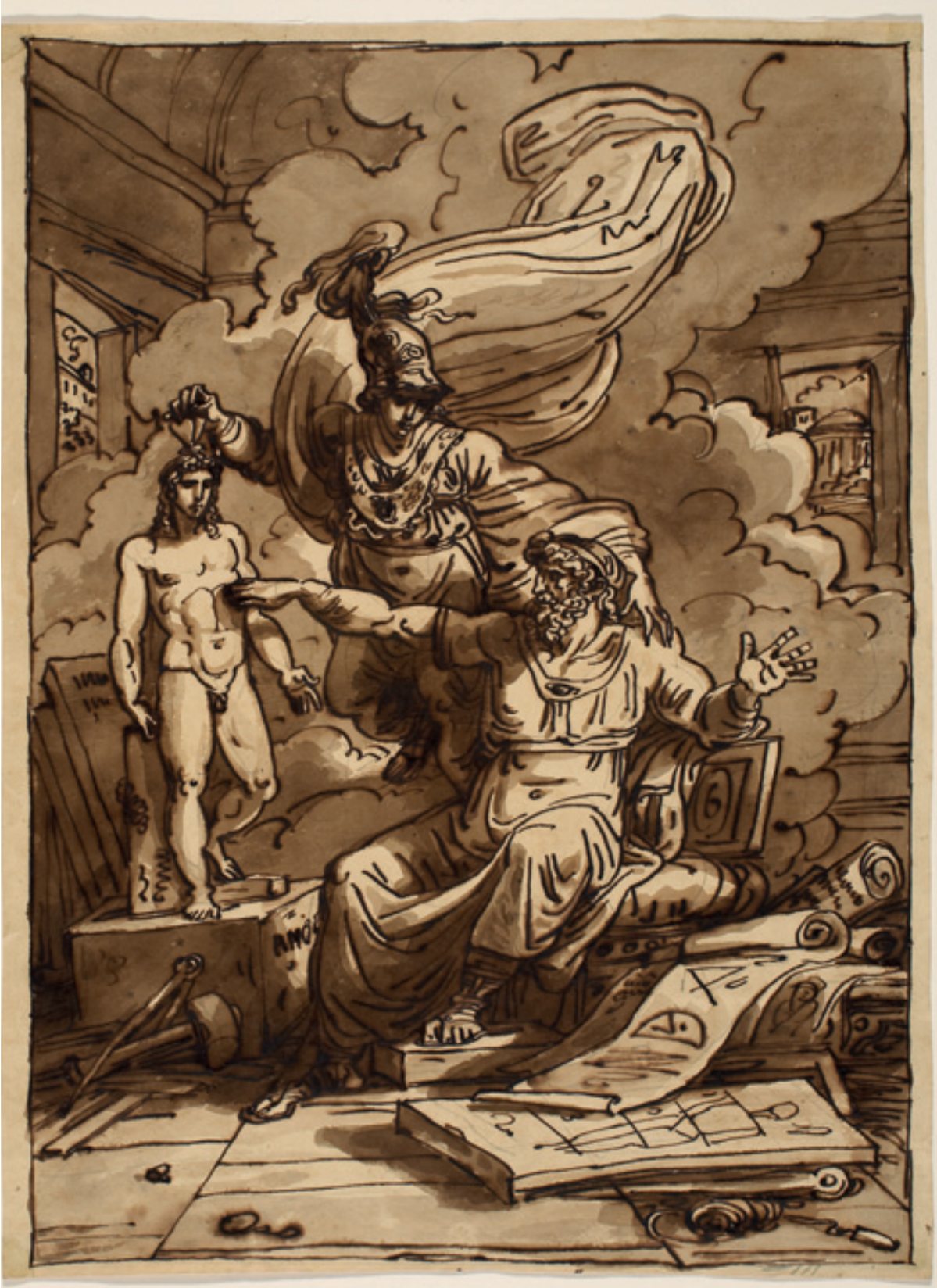

Figur 1 Prometheus har modellert sitt menneske i leire, mens Athene holder sommerfuglen over skapelsens hode. Det greske ordet for sommerfugl er det samme som for ordet ånd, pust eller sjel, nemlig psyke. Felice Giani. Prometheus skaper det første mennesket, ca. 1810-15. Blyant overtegnet med penn og brunt blekk på tonet papir overmalt med brunt. 50,1 ×37,4 cm. National Gallery of Canada, Ottawa. Photo (c) NGC

unikhet kan gjenkjennes det kulturhistorikerne Nelkin og Lindee har kalt genetisk essensialisme: forestillingen om at mennesket $\mathrm{i}$ all sin kompleksitet kan reduseres til en molekylær tekst - DNA-molekylet (2). En slik reduksjonisme er også betingende: i den molekylære teksten står fremtiden tegnet, som en deterministisk kode for menneskenes personlighet og individualitet. Når cellematerialet kan mangfoldiggjøres gjennom kloning, utfordres forestillingen om individet som enestående og unikt. Kloning innebærer kopiering av en celles genetiske materiale men hva om hele identiteten også ligger festet der? Kopieres kroppen, eller hele mennesket? Forestillingen om genetisk essensia- lisme åpner for at «kloning» ikke kun var duplisering eller mangfoldiggjøring av kropper, men samtidig også duplisering og mangfoldiggjøring av «sjel», «ånd» eller «selv»-eller identitet. At individets unikhet utelukkende er å finne i det genetiske materialet, er selvsagt en forenkling av virkeligheten, men det er en forenkling som har stor kulturell gjennomslagskraft (4).

Filosofen Hans Jonas beskriver hvordan den ideelle klon (til bruk for øvelse i foregripende fantasi og etisk refleksjon) «ikke skal være en reise til det ukjente, men tvert imot til det fullstendig kjente» (5). Kloning forstått som en reise til det kjente understreker den potensielle muligheten til å se seg selv som den andre, se sitt eget speilbilde og sin egen inkarnasjon - og den andre som en stedfortreder for seg selv. Innsikter fra det store genomprosjektet, sluttfort i 2000, og genetisk ingeniørkunst hadde åpnet for de potensielle mulighetene til å skreddersy mennesker til spesielle formål. Men uttrykk som «designerbarn», «prøverørsbarn», «human body shop» og «sorteringssamfunn» fikk nytt innhold da man gjennom kloningen sto overfor muligheten av å mangfoldiggjøre slike skapninger.

Sauen Dolly ble unnfanget i et prøverør. Hennes tilblivelse åpnet imidlertid for langt mer svimlende perspektiver enn det den foregående reproduktive teknologien in vitro-fertilisering (eller såkalt kunstig befruktning) noensinne hadde gjort. Med Dolly ble slektslinjer og forestillinger om opphav utfordret: En far var overflødig, og slekt fulgte ikke lenger slekters gang. Dolly var genetisk sett seg selv, skapt om igjen. Men var hun sin egen mor, eller sin egen datter? Var hun sin egen original, eller sin egen kopi? Var hun en av mange kopier? Hun kunne tenkes å eksistere i flere utgaver på samme tid, mangfoldiggjort i endeløse rekker. Dolly kunne også prinsipielt erstattes av nyere utgaver av seg selv og derved inngå i en endeløs rekke av identiske individer, og derigjennom oppnå en form for evig liv. Hennes anvendelsesområde kunne også tenkes reversert: Med tilgang på den nye teknologien skulle man også kunne hente tilbake et spesifikt individ fra de døde. Ny vitenskap og teknologi kunne lykkes der Orfeus kom til kort.

Scenariene ovenfor kan betraktes som varianter av det samme: De uttrykker de nye teknologienes potensial for å kunne skape mennesker i en annens sted, det være seg som donorer, reservedelslagre, stedfortredere, dupliseringer eller kopier. Satt opp mot den utbredte forestillingen om at ethvert menneske er unikt, peker alle mot tap av identitet, eller i siste instans, menneskets menneskelighet.

Freuds begrep unheimlich - at noe på samme tid er familiært og fremmed, og vekker en ubestemmelig følelse av uro - kan anvendes på Dolly. Den mildt utseende sauen er til forveksling lik andre sauer, men skjuler hemmeligheter under sine fåreklær. Begrepet kan også brukes på klonede og andre «kunstige mennesker». De likner oss, de kan se ut som oss, men de vekker samtidig en distinkt uro om at de er noe annet. Kunstige mennesker kan betraktes som et uttrykk for menneskets andre: det er stedfortrederen, dobbeltgjengeren, surrogatene. Forestillinger om kunstige mennesker eksisterer som kontinuerlige grensedragninger opp mot mennesket selv. Ny teknologi reaktualiserer gamle spørsmål om hva mennesket er.

\section{Fiksjonens nærvær}

Et helt sentralt og påfallende trekk ved fenomenet Dolly er fiksjonens nærvær. Én 
formulering ble repetert som et mantra da nyheten om Dollys fødsel ble kjent: Det var som om science fiction ble virkelighet.

Det fantes en offentlig bevissthet om klonede mennesker lenge før Dolly. En uendelighet av kloningstematikker er blitt utforsket i populærkulturen, gjennom film, litteratur, tegneserier og reklame. Samtidig er klonene kun en av mange varianter innenfor den eldre og langt bredere kategorien «kunstige mennesker» - mennesker skapt uten seksualitet, ved hjelp av ny teknologi og animert ved guddommelig assistanse eller vitenskap. Kunstige mennesker har aldri eksistert, men som tenkte muligheter har de en lang historie innenfor myter, vitenskap, kunst, musikk, populærkultur og litteratur. De er representert som animerte statuer, androider, automater, kyborger, roboter - skikkelser som synes å få nytt liv når ny teknologi igjen aktualiserer spekulasjoner om det kunstige menneskets komme (fig 1).

I forsøkene på å beskrive og forstå fenomenet Dolly oppsto en omfattende og kompleks kulturell praksis, der referansene til fiksjon, science fiction og populærkultur sto sentralt. Det er godt dokumentert gjennom systematiske undersøkelser av medieoppslag, fokusgrupper og spørreundersøkelser hvordan slike referanser ble bredt tatt i bruk, av både journalister og publikum (6). En representativ undersøkelse fra Wellcome Trust beskriver hvordan publikum trakk forbindelsen mellom kloning og kunstige mennesker: «Cloning - I mean it's Frankenstein-type medicine»... «You see it on films, armies of marching robots. Why do we need cloning?» (7). Man refererte til bøker og filmer, som Boys from Brazil, Jurassic park, Blade runner, Invasion of the bodysnatchers, Frankenstein, Brave new world, Star trek og Alien - uten at det ble klart hvilke aspekter ved filmene man alluderte til. Referansene ble nærmest betraktet som selvforklarende, som selvstendige metaforer der ytterligere forklaringer og utdypning var overflødige.

To av de mest sentrale referansene i kontroversen knyttet til Dolly var Brave new world og Frankenstein. Et knippe overskrifter som dekket nyheten om Dolly er illustrerende: «Dolly - scientific breakthrough or Frankenstein's monster?», «Cloned cells - Frankenstein or saviour of humanity?», «The Frankenstein monster ended up being a lamb», «Dolly - into Brave new world?» og «Brave new sheep» (8).

Om ikke publikum nødvendigvis kjenner selve tekstene, er titlene Frankenstein og Brave new world allerede kulturelt etablert som meningsbærende, gjennom uendelige gjenfortellinger via film, tegneserier, karikaturer, bilder og metaforer. Selve boktitlene har antatt nærmest myteliknende trekk. Forfatterne har til felles at de spekulerer i kunstig reproduksjon av mennesker, og skriver seg derved inn i en gammel kulturell tradisjon. Samtidig byr de på en viktig nyskapning: I begge tekstene skapes kunstige mennesker gjennom moderne vitenskap og teknologi, og uten guddommelig assi-

stanse. Dette gjør dem svært anvendbare for å tematisere kunstige mennesker og kloning. Tekstene har også langt bredere nedslagsfelt: De er etablert som kulturelle referanser for skepsis knyttet til anvendelse av vitenskap og teknologi generelt. Samtidig er tekstenes imaginære kunstige mennesker muliggjort gjennom intervenering i og omkoding av natur. Dette kan forklare at de også er mye anvendt i populære beskrivelser av nyvinninger innen bioteknologi spesielt. I det følgende skal jeg skissere litt av bredden i bruken av disse referansene knyttet til både kloning og bioteknologi. De ble ikke kun tatt i bruk av medier og publikum, men også av vitenskaperne selv.

Frankenstein, or the modern Prometheus, ble skrevet av16-åringen Mary Shelley, og publisert i 1818. Romanen (som i tittellinjen alluderer til den antikke Prometheusmyten) er opphavet til den såkalte «Frankenstein-myten» - en moralsk fabel om vitenskapens uforutsette konsekvenser: Skaper- verket vender seg mot sin skaper i destruksjon og ødeleggelse. Ut fra sin manipulering av naturen er «Frankenstein» også beskrevet som «the governing myth on modern biolology» (9). «Frankenstein» forveksles gjennomgående med sitt ukontrollerbare monster, og skaperen låner derved trekk og farge fra sitt skaperverk (fig 2).

Aldous Huxleys Brave new world fra 1932 er en fremtidsvisjon om et totalitært samfunn med spesialdesignede mennesker tilpasset sin skjebne gjennom systematisk anvendelse av biologi, teknologi, psykologi, og tilgang på fri sex og gratis dop. Alle er lykkelige, men frarøvet friheten til å forstå seg selv og andre som unike individer.

Disse bøkene er viktige litterære forelegg for velbrukte metaforer som «prøverørsbarn», «reservedelsmennesket», «the human body shop» og «den gale professoren».

I Huxleys Brave new world knyttes flaskebarna til masseproduksjon, og alluderer til «samlebåndsmennesker» uten identitet. A dyrke frem barn i flasker er imidlertid ingen ny idé. Et prosjekt innen alkymien var nettopp skapelse av en homunculus

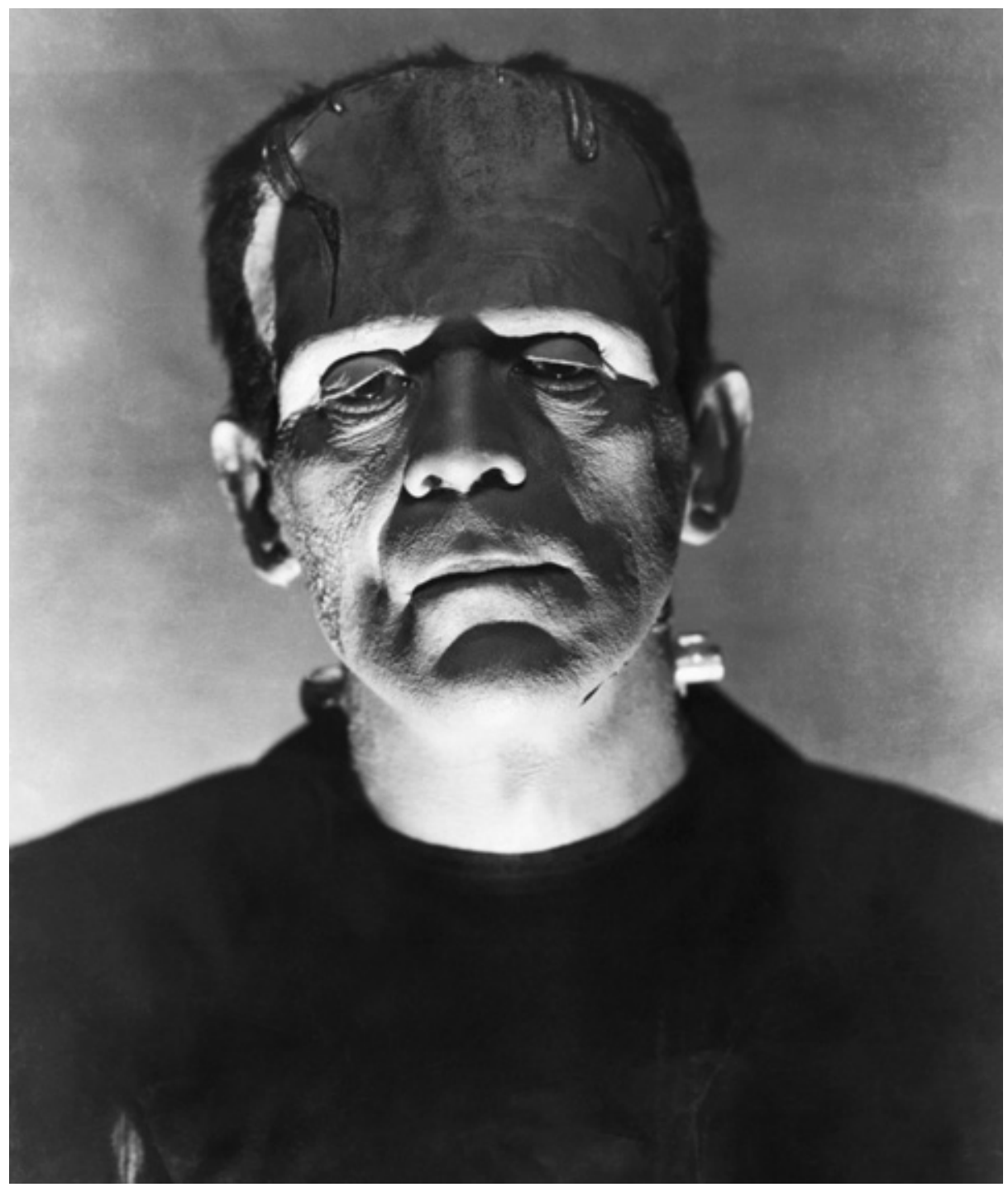

Figur 2 Boris Karloff som Frankenstein i James Whales Frankenstein (1932). SCANPIX/Corbis 


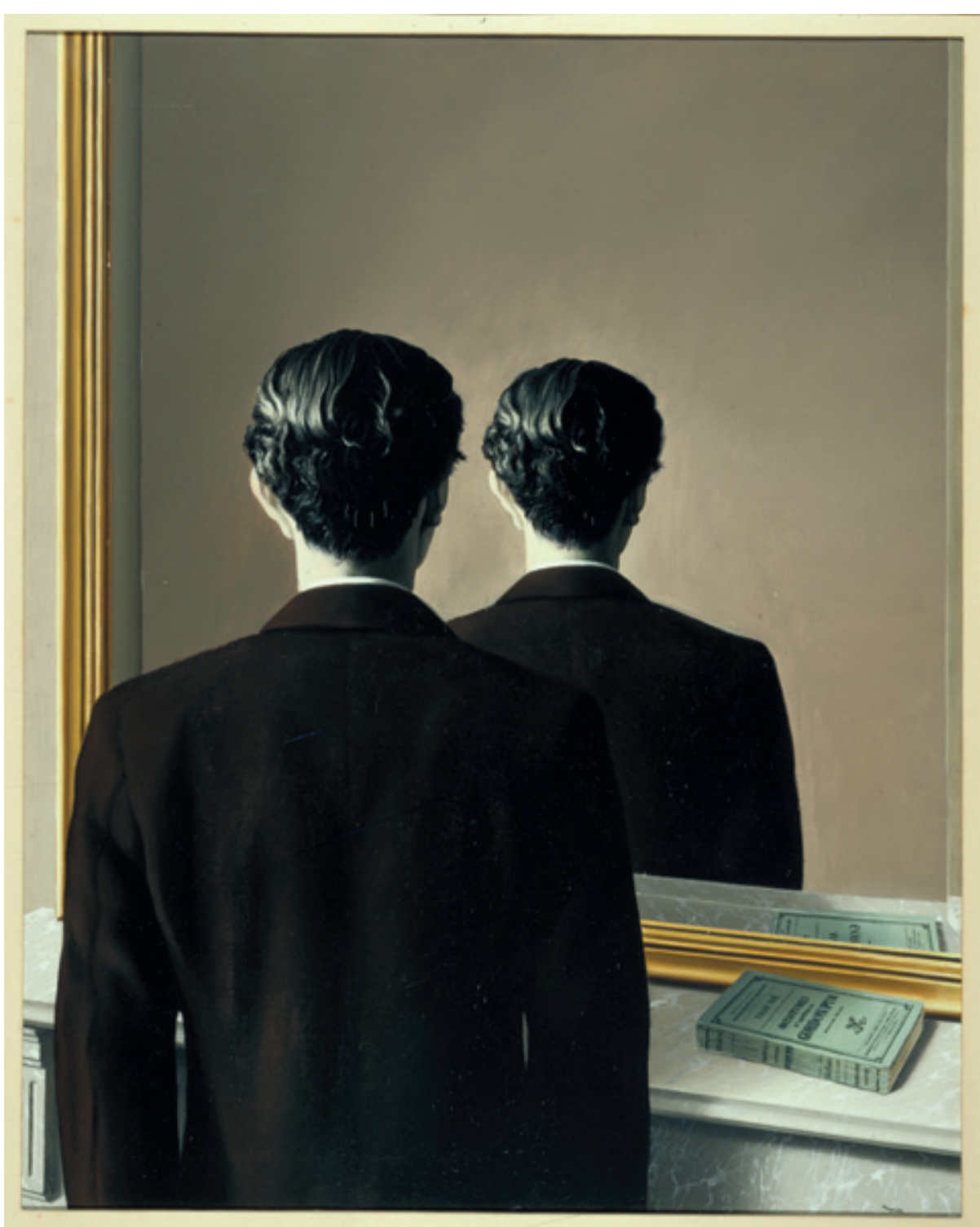

Figur 3 René Magritte (1937): Not to be reproduced. René Magritte La reproduction Museum Boijmans Van Beuningen, Rotterdam

- et «lite menneske», frembrakt i laboratoriet, i en glassflaske. I On the nature of things fra 1650 leverte alkymisten Paracelsus en detaljert fremgangsmåte. Denne tok Goethe senere som utgangspunkt for sin litterære og dypt tvetydige skapelse av det lille menneske, Homunculus, i Faust II. Metaforens forbindelse til førmoderne vitenskap illustrerer hvordan gamle lag av forståelse kan forbindes med ny teknologi og skapelsen av kunstige mennesker; metaforene rommer allusjoner til metafysikk, demoniske krefter, Gud og verdensaltet.

Metaforer som «reservedelsmenneske» og «the human body shop» har litterære forelegg i fortellingen om Frankenstein boken er blant annet beskrevet som vestlig histories første eksempel på body engineering (9). Frankenstein skaffet kroppsdeler ved å plyndre kirkegårder og stjele fra likhus, komponerte dem i stor dimensjon og sydde dem sammen til det som skulle bli «det perfekte menneske». Frankenstein- metaforen er også mye anvendt i diskusjoner knyttet til handelen av organer (10).

Frankenstein er også en av de mest velbrukte kulturelle referansene til forestillingen om «den gale vitenskapsmannen» (11). Den gale vitenskaperen personifiserer det gamle curiositas, og beskrives ofte gjennom sin vilje til å sette seg i Guds sted - å kontrollere naturen og skaperverket gjennom vitenskapelig innsikt. Et sentralt Faust-motiv er klart identifiserbart i denne forestillingen: forbindelsen mellom streben etter kunnskap og demoniske krefter. Frankenstein som «gal vitenskapsmann» alluderer også ofte til tilsvarende typer «gale vitenskapere» - som «alkymisten», eller «trollmannens læregutt».

Kloningsdiskursene var ikke utelukkende knyttet til science fiction-fortellinger og myter. Også vitenskapen selv har utgjort viktige kilder til nye fortellinger om banebrytende kunnskap - samtidig som fiksjonen gjennomgående har spekulert i den nye vitenskapens potensial. Dette sam- spillet er viktig, og bygger sammen fiksjon og vitenskap. I tilfellet Dolly ble en rekke metaforer fra fiksjonens verden tatt $\mathrm{i}$ bruk, men metaforene alluderte også til «historier» fra tidligere gjennombrudd innenfor genetikk og reproduktiv medisin. I den offentlige debatten om kloning var såkalte konseptuelle metaforer som «(cloned) children are products» og «(cloned) children are spare parts» mye anvendte metaforer (12). Slike konseptuelle metaforer trekker på en kombinasjon av kulturelle forestillinger om teknologien kloning kombinert $\mathrm{md}$ in vitro-fertilisering og genetisk ingeniørkunst. Brave new world var flittig benyttet i kontroversene knyttet til slik fertilisering, prøverørsbarn og det såkalte sorteringssamfunnet (13). Navnet Frankenstein - eller rettere sagt, første del av det ble knyttet til genmodifiserte organismer, eller genmodifisert mat, såkalte GMOs (genetically modified organisms).

Såkalte «Frankenphemes» som «Frankenfish» og «Franken-food» mer enn antyder natur som er bioteknologisk tuklet med. Begrepene alluderer til et monstrøst resultat der konsekvensene er uforutsigbare og farlige - og repeterer og befester samtidig den etablerte populærkulturelle praksisen med å forveksle Frankenstein med Monsteret: Den nye skapningen slår tilbake på skaperen selv.

Nyheten om Dolly bidro til en sterk økning av medienes opptatthet av bioteknologi generelt, og kloning spesielt (3). Mange kritikere har diskutert det negative fokus som ble kloningen til del, og forklart reaksjonene med «a media weaned on a diet of cloning scare stories and pulp fiction» (12).

Med sin sterke anvendelse av (negative) metaforer og bilder fra fiksjonens verden ble mediene beskyldt for å forenkle vitenskapen, for «selling science short», for å tåkelegge, skape sensasjon, nøre opp om frykt og styre offentligheten. Forskerne forsvarte sin vitenskap, og forsøkte raskt å nyansere bildet og etablere et skarpt skille mellom reproduktiv og terapeutisk kloning. I et intervju under overskriften «Dr. Frankenstein, I presume?» bekreftet Ian Wilmut at reproduktiv kloning av mennesket var innen rekkevidde, men understreket at det kun var den terapeutiske kloningen som var av forskningsmessig interesse - et perspektiv han flere ganger senere har fastholdt og utdypet (14). Wilmuts stemme er representativ for forskernes $i$ all hovedsak velvillige perspektiver reaksjonene på kloningen av Dolly var fra forskerhold «on the whole, friendly» - uten at dette hadde synderlig innflytelse på den dreiningen diskusjonene og reaksjonene tok de første årene etter 1997 (15).

Forskere selv hadde imidlertid lenge vært oppmerksomme på bioteknologiens etiske konsekvenser - og tok tidlig i bruk metaforer fra populærkulturen nettopp for å trekke vitenskapen ut i offentligheten og gjøre konsekvensene til et etisk anliggende. Genetikeren James D. Watson, kjent for 
DNA-molekylet og nobelprisen, understreket i en kongresshøring over temaet menneskelig kloning i 1971 hvordan dette ikke var opp til forskerne, men en avgjørelse som måtte tas av «the general public do you want this or not?» (15). Williard Gaylin, psykiater og en av grunnleggerne av det senere Hastings Center, dramatiserte Watsons advarsler i en artikkel i New York Times Magazine $i 1972$ - nettopp i håp om å vekke offentlighetens interesse for bioteknologiens etiske implikasjoner. Artikkelen bar tittelen «The Frankenstein myth becomes a reality - we have the awful knowledge to make excact copies of human beings» (16).

I det omfattende kildematerialet om kloning i medier og populærkultur, og de mange analysene av dette stoffet, er det et gjennomgående perspektiv: Kloning er uløselig forbundet med en generell ambivalens som angår kunnskap generelt og bioteknologi spesielt (17). Dolly vakte frykt og fascinasjon, og reaksjonene beveget seg fra forventninger om fremskritt og mirakler til undergang og apokalypse.

Den utbredte refereringen til kulturelle representasjoner kan forklares med at vi forsøker å anskueliggjøre og begrepsfeste våre erfaringer. Kulturelle representasjoner kan betraktes som redskaper som kan hjelpe til å formulere kompliserte forestillinger, og til å begripe det som fremstår som mer eller mindre ubegripelig (2). Gjennom å referere til kjente kulturelle representasjoner vekkes assosiasjoner som kan gi kulturell gjenklang, og derved gi en bekreftelse på en felles forståelse av en kompleks situasjon.

Metaforer er en uløselig del av vår daglige tanke og tale. I Metaphors We Live By har Lakoff \&Johnson argumentert for at vårt konseptuelle system hovedsakelig er metaforisk - hvilket vil si at våre måter å tenke på, erfare og handle struktureres av metaforene. Det innebærer nødvendigvis også at metaforene er mer enn et «medium»: De bidrar til å forme og prege det som omtales - i dette tilfellet våre oppfatninger av ny vitenskap og teknologi. Ved å formulere det ukjente i kjente termer og kategorier, og derved inkludere det ukjente i velkjente sammenhenger og kontekster, flytter vi noe av det vi vet om ett område av livet over på det som er ukjent (18). Gjennom kulturelle uttrykk knyttes ny teknologi til gamle spørsmål, til tidligere fortellinger der liknende temaer er tematisert. De bidrar til å legge nye lag av forståelser og nyanser til et komplekst møte med en ny potensiell virkelighet - og til å nyfortolke de etablerte kulturelle formene.

Når kjente metaforer og kulturelle referanser anvendes, bringer de også inn deler av fortidige fortellinger, og gjør dem tilgjengelige for ny anvendelse, en anvendelse som i dette tilfellet blir utformet $i$ en ny vitenskapelig, sosial og kulturell kontekst (19).

\section{Fiksjon og forventninger}

Dolly er selv blitt en kulturell metafor for kloning. Slike metaforer projiserer kulturhistoriske erfaringer inn i samtiden, og disse erfaringene bringer også med seg forventninger om en fremtid (20). Da kloning av mennesker syntes å være innen teknisk rekkevidde, ble fortellinger om kunstige mennesker fra tiden $f ø r$ dette var teknisk mulig aktivert. Verken klonede eller andre kunstige mennesker hadde sett dagens lys, men deres eksistens og skjebne er talløse ganger blitt utforsket i mytenes og fiksjonens verden, oftest i form av dystopier. Det var slike fortellinger medier og publikum grep til da nyheten om sauen Dolly ble presentert. Gamle fortellinger om kunstige mennesker inngår som kulturelle erfaringer, og de legger foringer på hvordan vi forholder oss til ny reproduktiv teknologi. De bidrar til å skape kulturelle forventninger: Fiksjonens fortellinger om kunstige mennesker har foregrepet kloningens potensielle konsekvenser.

Et gjennomgående, men dobbelt budskap fra fiksjonens verden er at det er teknisk mulig å lykkes med å skape kunstige mennesker - samtidig som det svært ofte mislykkes sosialt, kulturelt og eksistensielt. Utfordringene ved den nye teknologien er ikke primært at det blir teknisk mulig, men hva slags konsekvenser det kan få. Litterære og kulturelle fortellinger om kunstige mennesker spekulerer i muligheter knyttet til ny reproduktiv teknologi og formulerer episke scenarier om hva slags skapning som potensielt kan se dagens lys.

Dolly viste den nye teknologiens potensielle muligheter og konsekvenser, og ble en mangetydig manifestasjon av bioteknologisk suksess. Hun var et uttrykk for den største triumf: Gjennom anvendelse av vitenskap og teknologi kunne mennesket kontrollere og manipulere naturen i den grad at nytt liv, at mennesket selv, kunne skapes på kunstig vis. Men hun vakte i høyeste grad også uro og frykt: denne vitenskapen og teknologien hadde potensial til å gripe inn i og endre naturen, og menneskeheten, for bestandig. Hun reaktualiserte og reformulerte gamle spørsmål knyttet til vitenskapelig kunnskap generelt og til teknologisk tukling med naturen spesielt, og i siste instans, til det store spørsmålet om hva mennesket er. Dolly representerte en historisk helt ny situasjon der klonede mennesker ikke lenger bare var tenkelig, men også teknisk mulig. De påfallende sterke reaksjonene handlet ikke om sauen, men om forventninger til at det klonede menneske var innen umiddelbar rekkevidde (fig 3).

Oppgitte interessekonflikter: Ingen

\section{Litteratur}

1. Berg SF. Ny teknologi, gamle forestillinger. Kloning og kunstige mennesker i Shelleys Frankenstein, Goethes Faust II og Huxleys Brave new world. Doktoravhandling. Oslo: Senter for teknologi, innovasjon og kultur, Universitetet i Oslo, 2010
2. Nelkin D, Lindee S. Cloning in the popular imagin ation. I: Klotzko AJ, red. The cloning sourcebook. New York: Oxford University Press, 2003

3. Einsiedel EF. Cloning and its discontents-a Canadian perspective. Nat Biotechnol 2000; 18: 943-4.

4. Nelkin D, Lindee S. The DNA mystique. The gene as a cultural icon. Oxford: Freeman, 1995

5. Jonas H. Technik, Medizin und Ethik : zur Praxis des Prinzips Verantwortung. Frankfurt am Main: Suhrkamp, 1985

6. Haran J, Kitzinger J. McNeil Maureen et al. Human cloning in the media. From science fiction to science practice. London: Routledge, 2008.

7. Trust W. Medicine in Society Programme. Public perspectives on human cloning. A social research study. London: Wellcome Trust, 1998

8. Einsiedel E, Allansdottir A, Allum NC et al. Brave new sheep. I: Bauer MW, Gaskell G, red. Biotechnology: the making of a global controversy. Cambridge: Cambridge University Press, 2002.

9. Turney J. Frankenstein's footsteps: science, genetics and popular culture. New Haven, CT: Yale University Press, 1998.

10. Andrews L, Nelkin D. Body bazaar. The market for human tissue in the biotechnological age. New York, NY: Crown, 2001

11. Haynes R. From Faust to Strangelove: representations of the scientist in western literature. Baltimore, MD: Johns Hopkins University Press, 1994.

12. Nerlich B, Clarke D, Dingwall R. The influence of popular cultural imagery on public attitudes towards cloning. Sociological Research Online 4. www.socresonline.org.uk/4/3/nerlich.html (1.9.2010).

13. Squier S. Babies in bottles. Twentieth-century visions of reproductive technology. New Brunswick, NJ: Rutgers University Press, 1994.

14. Ross A. Dr. Frankenstein, I presume? Salon Magazine 24.2.1997

15. Wilkie T, Graham E. Power without responsibility: media portrayals of Dolly and science. I: Klotzko AJ, red. The cloning sourcebook. New York, NY: Oxford University Press, 2003

16. Human cloning and human dignity: the report of the President's Council of Bioethics. New York. NY: PublicAffairs, 2002

17. Gaskell G, Bauer MW, red. Biotechnology 1996-2000. The years of controversy. London: Science Museum, 2001

18. Lakoff G, Johnson M. Metaphors we live by. Chicago, IL: University of Chicago Press, 1980.

19. Strathern M. Reproducing the future. Essays on anthropology, kinship and the new reproductive technologies. Manchester: Manchester University Press, 1992.

20. Koselleck R. Space of experience and horizon of expectation. I: Koselleck R, red. Futures past. On the semantics of historical time. San Diego, CA: Greenhaven Press, 1999

Mottatt 6.9. 2010, godkjent 4.11. 2010

Medisinsk redaktør Anne Kveim Lie. 